\title{
Annotated checklist of brachyuran crabs (Crustacea: Decapoda) of the Iberian Peninsula (SW Europe)
}

\author{
Elena Marco-Herrero ${ }^{1}$, Pere Abelló ${ }^{2}$, Pilar Drake ${ }^{1}$, Jose Enrique García-Raso ${ }^{3}$, \\ Juan Ignacio González-Gordillo ${ }^{4}$, Guillermo Guerao ${ }^{5}$, Ferran Palero ${ }^{6}$, Jose A. Cuesta ${ }^{1}$ \\ ${ }^{1}$ Instituto de Ciencias Marinas de Andalucía, CSIC, Campus de Excelencia Internacional del Mar, \\ Avda. República Saharaui, 2, 11519 Puerto Real, Cádiz, Spain. E-mail: elena.marco@csic.es \\ ${ }^{2}$ Institut de Ciències del Mar, CSIC, Passeig Marítim de la Barceloneta 37-49, 08003 Barcelona, Spain. \\ ${ }^{3}$ Universidad de Málaga, Departamento de Biología Animal, Facultad de Ciencias, Campus de Excelencia Internacional del Mar, \\ Campus de Teatinos s/n, 29071 Málaga, Spain. \\ ${ }^{4}$ CACYTMAR, Campus de Excelencia Internacional del Mar, Universidad de Cádiz, 11510 Puerto Real, Cádiz, Spain. \\ ${ }^{5}$ Passeig Fabra i Puig 344, 08031 Barcelona, Spain. \\ ${ }^{6}$ INRA, Univ. Nice Sophia Antipolis, CNRS, UMR 1355-7254 Institut Sophia Agrobiotech, \\ 06900 Sophia Antipolis, France.
}

\begin{abstract}
Summary: Almost 50 years have passed since a group of reputed carcinologists (viz. Lipke B. Holthuis, Isabella Gordon and Jacques Forest) finished the posthumous work of Ricardo Zariquiey Álvarez (1968) on decapod crustaceans of the Iberian Peninsula. No lists of decapod fauna specifically covering this area have been published since then, and an update is needed. The current list of brachyuran crabs of the Iberian Peninsula comprises 140 species, which is 35 species more than the 105 valid species listed in Zariquiey Álvarez (1968). Systematic changes have affected the original classification, so now there are 20 superfamilies, 36 families and 77 genera. Additional species have been recorded in Iberian waters due to natural range expansions from nearby areas (Mediterranean and Atlantic), introductions by anthropogenic activities, and description of new taxa. Also, two species were synonymized. Several of these changes, based on evidence from larval morphology and/ or molecular data, are detailed in this review. Although descriptions of crab species new to science are not expected to occur at a significant rate, an increase in the number of species in the Iberian Peninsula is expected to result from the introduction of alien species.
\end{abstract}

Keywords: checklist; Brachyura; Crustacea; Decapoda; crab; Iberian Peninsula.

Lista comentada de los cangrejos braquiuros (Crustacea: Decapoda) de la península Ibérica (SO Europa)

Resumen: Han pasado casi 50 años desde que un grupo de reputados carcinólogos (viz. Lipke B. Holthuis, Isabella Gordon y Jacques Forest) finalizaran la obra póstuma de Ricardo Zariquiey Álvarez (1968), "Crustáceos decápodos de la Península Ibérica". Desde entonces no se ha publicado una lista de la fauna de decápodos que cubra específicamente este área, y era necesaria una actualización. La lista actual de braquiuros de la Península Ibérica consta de un total de 140 especies, 35 especies más de las 105 especies válidas enumeradas en Zariquiey Álvarez (1968). Los cambios en la sistemática han afectado la clasificación original, por lo que ahora hay 20 superfamilias, 36 familias y 77 géneros. Otras especies han sido citadas en aguas ibéricas debido a expansiones naturales de su rango de distribución desde áreas cercanas (Mediterráneo y Atlántico), a las introducciones mediadas por las actividades antropogénicas y a la descripción de nuevas especies. Además, se han sinonimizado dos especies. Varios de estos cambios, basados en evidencias de la morfología de las larvas y/o datos moleculares, se detallan en esta revisión. Aunque no se espera que las descripciones de nuevas especies de cangrejos para la ciencia se produzcan a un ritmo significativo, si es esperable un incremento en el número de especies en la Península Ibérica como resultado de la introducción de especies exóticas.

Palabras clave: lista; Brachyura; Crustacea; Decapoda; cangrejo; península Ibérica.

Citation/Como citar este artículo: Marco-Herrero E., Abelló P., Drake P., García-Raso J.E., González-Gordillo J.I., Guerao G., Palero F., Cuesta J.A. 2015. Annotated checklist of brachyuran crabs (Crustacea: Decapoda) of the Iberian Peninsula (SW Europe). Sci. Mar. 79(2): 243-256. doi: http://dx.doi.org/10.3989/scimar.04161.27A

Editor: C. Froglia.

Received: October 17, 2014. Accepted: February 23, 2015. Published: March 31, 2015.

Copyright: (C) 2015 CSIC. This is an open-access article distributed under the Creative Commons Attribution-Non Commercial License (by-nc) Spain 3.0. 


\section{INTRODUCTION}

Almost 50 years have passed since a group of reputed carcinologists (viz. Lipke B. Holthuis, Isabella Gordon and Jacques Forest) finished the posthumous work of Ricardo Zariquiey Álvarez (1968) on decapod crustaceans of the Iberian Peninsula. This geographic area has over $6000 \mathrm{~km}$ of coastline and is washed by the warm and oligotrophic Mediterranean Sea in the east and by the colder Atlantic Ocean in the west, which converge at the Strait of Gibraltar (Fig. 1). The high environmental heterogeneity and the proximity between the European and African continents provide suitable conditions for a particularly diverse marine fauna. The extensive information compiled by Zariquiey Álvarez regarding habitat, spawning season and distribution of Iberian decapods made L.B. Holthuis (Zariquiey Álvarez 1968) state that "this peninsula is, in the present moment, one of the best known areas of South Europe concerning decapod fauna". After the work of Zariquiey Álvarez (1968), several authors have published updated lists of decapod fauna at different geographical scales, from European species by d'Udekem d'Acoz (1999) and Türkay (2001) to worldwide brachyuran decapods by $\mathrm{Ng}$ et al. (2008). However, none of these has specifically covered the diversity found around the Iberian Peninsula; and an update is needed for this area.

A great number of changes concerning the crustacean species found around the Iberian Peninsula have taken place in the last decades. These changes can be due to systematic modifications such as synonymizations (qualitative) or due to non-corroborated presence or newly reported species for the area (quantitative). The systematic research landscape on decapod crustaceans has changed dramatically in the last few decades as well. A general tendency during the last few years has been to increase the number of families, in most cases simply by raising the rank of extant subfamilies. Today's most widely used classifications have all appeared after the work of Zariquiey Álvarez (1968), including those by Guinot (1977), Bowman and Abele (1982), Martin and Davis (2001) or Ng et al. (2008). De Grave et al. (2009) have also listed all known suprageneric taxa of decapod crustaceans, with estimates on the number of valid species within each group. There is a concerted effort by carcinologists worldwide to check the validity of taxa using multiple tools such as ecological characterization, larval morphology and molecular techniques (Schubart et al. 2001, Reuschel and Schubart 2006, MarcoHerrero et al. 2013a).

The infraorder Brachyura Linnaeus, 1758 may be claimed to contain the highest degree of diversity among decapod crustaceans and includes both crab species with an important role in trophic webs as well as others of commercial interest. The main species of commercial interest found in Iberian waters are Maja brachydactyla, Maja squinado, Cancer pagurus and Necora puber; but Calappa granulata, Carcinus maenas, Carcinus aestuarii, Liocarcinus depurator, Geryon longipes and Uca tangeri are also important.

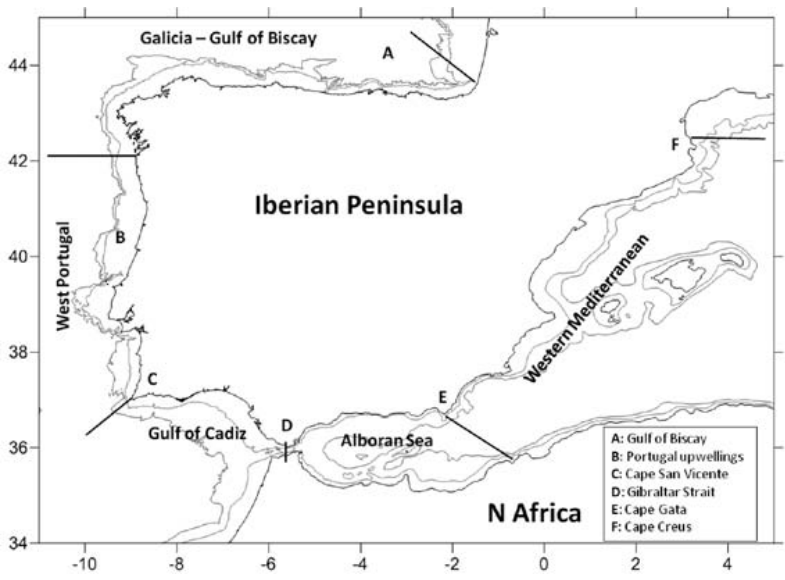

Fig. 1. Map of the Iberian Peninsula and nearby waters showing the different areas considered here to characterize the spatial distribution of brachyuran species. The 200- and 1000-metre isobaths are shown. Abbreviations: A, Gulf of Biscay; B, Portugal upwellings; C, Cape San Vicente; D, Gibraltar Strait; E, Cape Gata; F, Cape Creus.

Occasionally, other species may be seen in markets, such as Macropipus tuberculatus, Paromola cuvieri and Cancer bellianus. Several allochthonous species have been recorded in recent years and some may even show well-established populations. The present work summarizes all changes in Iberian carcinofauna since Zariquiey Álvarez (1968), and provides scientists with an updated classification list. Furthermore, the current status of brachyuran alien species throughout this region is thoroughly reviewed.

\section{MATERIALS AND METHODS}

The updated list of Iberian brachyuran crabs was drawn up in the context of the MEGALOPADN research project, which is focused on the use of morphological and molecular techniques for identifying planktonic larval stages. For the compilation of this list, all publications since 1968 about the distribution of brachyuran crabs were checked, including previous lists for Iberian or European regions, data from Internet databases such as WoRMS (http://www.marinespecies. org/), GBIF (http://www.gbif.org/species) and Observadores del Mar (http://www.observadoresdelmar.es/), systematic data, new records, and unpublished or in preparation data. Several contributions need to be highlighted here, mainly the works on European decapods carried out by d'Udekem d'Acoz (1999) and Türkay (2001), but also several specific works on Iberian carcinofauna (García Raso 1984, 1985, 1989, 1993, 1996, García Raso et al. 1987, García and Corbera 2007). In order to clarify the taxonomic status of controversial species and genera, the authors have checked multiple vouchers from the Natural History Museum (London), Muséum National d'Histoire Naturelle (Paris) and the Biological Reference Collections of the Institute of Marine Sciences (Barcelona) using morphology or molecular techniques.

This checklist covers all brachyuran species present in the Iberian Peninsula and Balearic Islands (see Fig. 1), including marine (from deep water to intertidal), 
brackish (estuaries, costal lagoons, marshes, ponds) and freshwater species (note that Eriocheir sinensis is considered a freshwater species here, although it depends on seawater for reproduction). The updated systematic classification follows $\mathrm{Ng}$ et al. (2008), but also considers the latest changes in particular taxa (e.g. new results by Spiridonov et al. (2014) on the Portunoidea). Superfamilies are listed by systematic order following the Sections and Subsections as currently accepted, and by alphabetical order within them. Families, genera and species are also listed by alphabetical order within their respective superfamilies and families. The tribe level has not been considered and the use of subgenera is left at a minimum.

All changes with respect to the work by Zariquiey Álvarez (1968) are explained, including new species, introduced alien species, synonyms, systematic modifications, species that reach Iberian waters by increasing their distribution range, and species no longer found in the Iberian Peninsula.

\section{RESULTS}

A total of 140 crab species are reported around the Iberian Peninsula, and their distribution is indicated in Table 1. This represents about half of the 284 brachyuran species known in European waters, of which 40 are freshwater crabs (d'Udekem d'Acoz 1999). It is also noteworthy that about two thirds of the currently accepted brachyuran superfamilies ( $\mathrm{Ng}$ et al. 2008, Spiridonov et al. 2014) are represented in the Iberian carcinofauna.

\section{REMARKS}

Systematic changes have affected the original classification of Brachyura, so instead of the 5 superfamilies, 20 families and 58 genera considered in Zariquiey Álvarez (1968), a total of 20 superfamilies, 36 families and 77 genera are presented here.

The current account of brachyuran crabs of the Iberian Peninsula adds another 35 to the 105 valid species in Zariquiey Álvarez (1968). Though a total of 113 brachyuran species were listed in his seminal work, five of these (Parthenope miersii, Portunus sayi, Euchirograpsus americanus, Grapsus grapsus and Percnon planissimum) should not be considered here because they are synonyms or misidentifications, or their presence in Iberian waters has not been confirmed. The Xantho incisus subspecies (X. incisus incisus and $X$. incisus granulicarpus) mentioned in Zariquiey Álvarez (1968), and considered as proper species by some authors (e.g. Mavidis et al. 2008), are not valid anymore. Although the morphology may be questionable (see García Raso et al. 1987, Mavidis et al. 2008), a recent genetic study did not allow their differentiation and $X$. incisus is considered here a synonym of $X$. hydrophilus (Reuschel and Schubart 2006).

Some additional species are now present in Iberian waters due to natural range expansions from nearby areas (Mediterranean and Atlantic), accidental intro- ductions by anthropogenic activities, and species new to science. For example, two species (Pisa carinimana and Paractaea monodi) had not been recorded along the Iberian coasts before Zariquiey Álvarez (1968). Several of these modifications are detailed below, most of them based on evidence from larval morphology and/or molecular data.

\section{Species no longer found in the Iberian Peninsula}

As noted above, five species included in Zariquiey Álvarez (1968) should not be considered as present in Iberian waters:

\section{Parthenope miersii (A. Milne-Edwards and Bouvier, 1898)}

This species has been collected only twice, the first time corresponding to a male collected at $112 \mathrm{~m}$ depth in the Gulf of Cádiz and used as holotype by A. Milne-Edwards and Bouvier $(1898,1900)$ and the second time corresponding to another male at 135-150 m depth in the Cape San Vicente (Nunes-Ruivo 1961). D'Udekem d'Acoz (1999) questioned the validity of this species based on two male specimens only, and Türkay (2001) considered that $P$. miersii is a synonym of Spinolambrus macrochelos.

\section{Portunus sayi (Gibbes, 1850)}

The records of this species in Cabo Espartel (NW Africa close to Gibraltar Strait) and in the Balearic Islands (Zariquiey Álvarez 1968) should be considered juveniles of Portunus hastatus according to Türkay (1987).

\section{Euchirograpsus americanus A. Milne-Edwards, 1880}

This species is only distributed in the western Atlantic, and all reports in Mediterranean and eastern Atlantic must be referred to E. liguricus (see Türkay 1975).

\section{Grapsus grapsus (Linnaeus, 1758)}

This species was reported along the coast of Portugal, once in Setubal (Osório 1905) and later on in Sesimbra (Vilela 1936). G. grapsus is mainly distributed in the western Atlantic, while Grapsus adscensionis is the main eastern Atlantic species of this genus (see Manning and Chace 1990). It is hard to imagine that $G$. grapsus could occur along the Iberian coast and pass unnoticed, taking into account the habitat (intertidal rocky shores) and typical size of this species. Given that there are no other reports for these species along the Iberian coast, $G$. grapsus was not included in this checklist.

\section{Percnon planissimum (Herbst, 1804)}

Zariquiey Álvarez (1968) reports this species as rare in the coastal and sub-coastal waters of Portugal. No reports have been published confirming its presence in Iberian waters. In the last few years though, Percnon gibbesi has been collected throughout the Mediterranean, and specifically from Mediterranean localities on the Iberian coast. 
Table 1. - List of brachyuran species present in the Iberian Peninsula. Abbreviations: ALB, Alboran Sea; GC, Gulf of Cadiz; G-GB, GaliciaGulf of Biscay; MED, Mediterranean Sea; WP, West Portugal. (+) present; $\left({ }^{1}\right)$ García Raso (unpublished data); $\left({ }^{2}\right)$ Rufino (unpublished data); ( $\left.{ }^{3}\right)$ Cuesta et al. (unpublished data); (?) not confirmed. Species marked with an asterisk were questioned in recent and ongoing studies as possible synonyms, and could be removed from the Iberian carcinofauna in the near future.

\begin{tabular}{|c|c|c|c|c|c|}
\hline Taxa/Species & G-GB & WP & stribu & ALB & MED \\
\hline \multicolumn{6}{|l|}{ BRACHYURA Linnaeus, 1758} \\
\hline \multicolumn{6}{|l|}{ PODOTREMATA Guinot, 1977} \\
\hline \multicolumn{6}{|l|}{ CYCLODORIPPOIDEA Ortmann, 1892} \\
\hline \multicolumn{6}{|l|}{ Cymonomidae Bouvier, 1898} \\
\hline Cymonomus granulatus (Thomson, 1873) & $(+)$ & $(+)$ & $(+)$ & $(+)$ & $(+)$ \\
\hline Cymonomus normani Lankester, 1903 & $(+)$ & $(+)$ & & & \\
\hline \multicolumn{6}{|l|}{ DROMIOIDEA de Haan, 1833} \\
\hline \multicolumn{6}{|l|}{ Dromiidae de Haan, 1833} \\
\hline Dromia personata (Linnaeus, 1758) & $(+)$ & $(+)$ & $(+)$ & $(+)$ & $(+)$ \\
\hline \multicolumn{6}{|l|}{ HOMOLODROMOIDEA Alcock, 1899} \\
\hline Homolodromiidae Alcock, 1899 & & & & & \\
\hline Dicranodromia mahieuxii A. Milne-Edwards, 1883 & $(+)$ & & & & \\
\hline HOMOLOIDEA de Haan, 1839 & & & & & \\
\hline Homolidae de Haan, 1839 & & & & & \\
\hline Homola barbata (Fabricius, 1793) & $(+)$ & $(+)$ & $(+)$ & $(+)$ & $(+)$ \\
\hline Homologenus boucheti Guinot and Richer de Forges, 1995 & & & $(+)$ & & \\
\hline Paromola cuvieri (Risso, 1816) & $(+)$ & $(+)$ & $(+)$ & $(+)$ & $(+)$ \\
\hline Latreilliidae Stimpson, 1858 & & & & & \\
\hline Latreillia elegans Roux, 1830 & & $(+)$ & $(+)$ & $(+)^{1}$ & $(+)$ \\
\hline EUBRACHYURA de Saint Laurent, 1980 & & & & & \\
\hline HETEROTREMATA Guinot, 1977 & & & & & \\
\hline CALAPPOIDEA de Haan, 1833 & & & & & \\
\hline Calappidae de Haan, 1833 & & & & & \\
\hline Calappa granulata (Linnaeus, 1758) & $(+)$ & $(+)$ & $(+)$ & $(+)$ & $(+)$ \\
\hline Calappa pelii Herklots, 1851 & & & & $(+)$ & \\
\hline Calappa tuerkayana Pastore, $1995 *$ & & & & & $(+)$ \\
\hline Cryptosoma cristatum Brullé, 1837 & & & $(+)^{2}$ & $(+)$ & \\
\hline CANCROIDEA Latreille, 1802 & & & & & \\
\hline Atelecyclidae Ortmann, 1893 & & & & & \\
\hline Atelecyclus rotundatus (Olivi, 1792) & $(+)$ & $(+)$ & $(+)$ & $(+)$ & $(+)$ \\
\hline Atelecyclus undecimdentatus (Herbst, 1783) & $(+)$ & $(+)$ & $(+)$ & $(+)$ & $(+)$ \\
\hline Cancridae Latreille, 1802 & & & & & \\
\hline Cancer bellianus Jonhson, 1861 & $(+)$ & $(+)$ & & & \\
\hline Cancer pagurus Linnaeus, 1758 & $(+)$ & $(+)$ & $(+)$ & & $(+)$ \\
\hline CORYSTOIDEA Samouelle, 1819 & & & & & \\
\hline Corystidae Samouelle, 1819 & & & & & \\
\hline Corystes cassivelaunus (Pennant, 1777) & $(+)$ & $(+)$ & $(+)$ & $(+)$ & $(+)$ \\
\hline DORIPPOIDEA MacLeay, 1838 & & & & & \\
\hline Dorippidae MacLeay, 1838 & & & & & \\
\hline Medorippe lanata (Linnaeus, 1767) & & $(+)$ & $(+)$ & $(+)$ & $(+)$ \\
\hline Ethusidae Guinot, 1977 & & & & & \\
\hline Ethusa mascarone (Herbst, 1785) & & $(+)$ & $(+)$ & $(+)$ & $(+)$ \\
\hline Ethusina talismani A. Milne-Edwards and Bouvier, 1897 & & $(+)$ & & & \\
\hline ERIPHIOIDEA MacLeay, 1838 & & & & & \\
\hline Eriphiidae MacLeay, 1838 & & & & & \\
\hline Eriphia verrucosa (Forskål, 1775) & $(+)$ & $(+)$ & $(+)$ & $(+)$ & $(+)$ \\
\hline GONEPLACOIDEA MacLeay, 1838 & & & & & \\
\hline Goneplacidae MacLeay, 1838 & & & & & \\
\hline Goneplax rhomboides (Linnaeus, 1758) & $(+)$ & $(+)$ & $(+)$ & $(+)$ & $(+)$ \\
\hline Progeryonidae Števčić, 2005 & & & & & \\
\hline Paragalene longicrura (Nardo, 1869) & & & & & $(+)$ \\
\hline LEUCOSIOIDEA Samouelle, 1819 & & & & & \\
\hline Leucosiidae Samouelle, 1819 & & & & & \\
\hline Ebalia cranchii Leach, 1817 & $(+)$ & $(+)$ & $(+)$ & $(+)$ & $(+)$ \\
\hline Ebalia deshayesi Lucas, 1846 & $(+)$ & $(+)$ & & $(+)$ & $(+)$ \\
\hline Ebalia edwardsii Costa, 1838 & & & $(+)$ & $(+)$ & $(+)$ \\
\hline Ebalia granulosa H. Milne-Edwards, 1837 & $(+)$ & & $(+)$ & $(+)$ & $(+)$ \\
\hline Ebalia nux A. Milne-Edwards, 1883 & $(+)$ & $(+)$ & $(+)$ & $(+)$ & $(+)$ \\
\hline Ebalia tuberosa (Pennant, 1777) & $(+)$ & $(+)$ & $(+)$ & $(+)$ & $(+)$ \\
\hline Ebalia tumefacta (Montagu, 1808) & $(+)$ & $(+)$ & $(+)$ & $(+)$ & $(+)$ \\
\hline Ilia nucleus (Linnaeus, 1758) & & & $(+)$ & $(+)$ & $(+)$ \\
\hline Merocryptus boletifer A. Milne-Edwards and Bouvier, 1894 & & & & & $(+)$ \\
\hline MAJOIDEA Samouelle, 1819 & & & & & \\
\hline Epialtidae MacLeay, 1838 & & & & & \\
\hline Acanthonyx lunulatus (Risso, 1816) & & & $(+)$ & $(+)$ & $(+)$ \\
\hline Anamathia rissoana (Roux, 1828) & & $(+)$ & & $(+)$ & $(+)$ \\
\hline Herbstia condyliata (Fabricius, 1787) & $(+)$ & & $(+)$ & $(+)$ & $(+)$ \\
\hline Lissa chiragra (Fabricius, 1775) & & $(+)$ & $(+)$ & $(+)$ & $(+)$ \\
\hline Pisa armata (Latreille, 1803) & $(+)$ & $(+)$ & $(+)$ & $(+)$ & $(+)$ \\
\hline Pisa carinimana Miers, 1879 & & & $(+)$ & $(+)$ & \\
\hline Pisa hirticornis (Herbst, 1804) & & & & $?$ & $(+)$ \\
\hline Pisa muscosa (Linnaeus, 1758) & & & & $(+)$ & $(+)$ \\
\hline Pisa nodipes (Leach, 1815) & $(+)$ & $(+)$ & & $(+)$ & $(+)$ \\
\hline
\end{tabular}




\begin{tabular}{|c|c|c|c|c|c|}
\hline \multirow{2}{*}{ Taxa/Species } & \multicolumn{5}{|c|}{ Distribution } \\
\hline & G-GB & WP & GC & ALB & MED \\
\hline Pisa tetraodon (Pennant, 1777) & $(+)$ & $(+)$ & $(+)$ & $(+)$ & $(+)$ \\
\hline Pisa sp. Marco-Herrero et al. (in prep.) & & & & $(+)$ & $(+)$ \\
\hline Rochinia carpenteri (Thomson, 1873) & $(+)$ & $(+)$ & $(+)$ & $(+)$ & $(+)$ \\
\hline \multicolumn{6}{|l|}{ Inachidae MacLeay, 1838} \\
\hline Achaeus cranchii Leach, 1817 & $(+)$ & & $(+)$ & $(+)$ & $(+)$ \\
\hline Achaeus gracilis (Costa, 1839) & $(+)$ & $(+)$ & $(+)$ & $(+)$ & $(+)$ \\
\hline Dorhynchus thomsoni Thomson, 1873 & $(+)$ & $(+)$ & $(+)$ & $(+)$ & $(+)$ \\
\hline Inachus aguiarii Brito Capello, 1876 & $(+)^{3}$ & $(+)$ & $(+)$ & $(+)$ & \\
\hline Inachus communissimus Rizza, 1839 & & & $(+)$ & $(+)$ & $(+)$ \\
\hline Inachus dorsettensis (Pennant, 1777) & $(+)$ & $(+)$ & $(+)$ & $(+)$ & $(+)$ \\
\hline Inachus leptochirus Leach, 1817 & $(+)$ & $(+)$ & $(+)$ & $(+)$ & $(+)$ \\
\hline Inachus phalangium (Fabricius, 1775) & $(+)$ & $(+)$ & & $(+)$ & $(+)$ \\
\hline Inachus thoracicus Roux, 1830 & & $(+)$ & $(+)$ & $(+)$ & $(+)$ \\
\hline Macropodia czernjawskii (Brandt, 1880) & & & $(+)$ & $(+)$ & $(+)$ \\
\hline Macropodia deflexa Forest, 1978 & $(+)$ & $(+)$ & & & \\
\hline Macropodia linaresi Forest and Zariquiey Álvarez, 1964 & $(+)$ & & $(+)$ & $(+)$ & $(+)$ \\
\hline Macropodia longipes (A. Milne-Edwards and Bouvier, 1899)* & $(+)$ & $(+)$ & $(+)$ & $(+)$ & $(+)$ \\
\hline Macropodia longirostris (Fabricius, 1775) & & & & $(+)$ & $(+)$ \\
\hline Macropodia parva Van Noort and Adema, $1985 *$ & & $(+)$ & $(+)$ & & \\
\hline Macropodia rostrata (Linnaeus, 1761 ) & $(+)$ & $(+)$ & $(+)$ & $(+)$ & $(+)$ \\
\hline Macropodia tenuirostris (Leach, 1814) & $(+)$ & $(+)$ & $(+)$ & $(+)$ & $(+)$ \\
\hline \multicolumn{6}{|l|}{ Majidae Samouelle, 1819} \\
\hline Eurynome aspera (Pennant, 1777) & $(+)$ & $(+)$ & $(+)$ & $(+)$ & $(+)$ \\
\hline Eurynome spinosa Hailstone, 1835 & $(+)$ & & $(+)$ & $(+)$ & $(+)$ \\
\hline Maja brachydactyla Balss, 1922 & $(+)$ & $(+)$ & $(+)$ & $(+)$ & \\
\hline Maja crispata Risso, 1827 & $(+)$ & $(+)$ & $(+)$ & $(+)$ & $(+)$ \\
\hline Maja goltziana d'Oliveira, 1888 & $(+)$ & $(+)$ & & & $(+)$ \\
\hline Maja squinado (Herbst, 1788) & & & & $(+)$ & $(+)$ \\
\hline \multicolumn{6}{|l|}{ Oregonidae Garth, 1958} \\
\hline Ergasticus clouei A. Milne-Edwards, 1882 & $(+)$ & $(+)$ & $(+)$ & $(+)$ & $(+)$ \\
\hline \multicolumn{6}{|l|}{ PALICOIDEA Bouvier, 1898} \\
\hline \multicolumn{6}{|l|}{ Palicidae Bouvier, 1898} \\
\hline Palicus caronii (Roux, 1828) & & & & $(+)$ & $(+)$ \\
\hline PARTHENOPOIDEA MacLeay, 1838 & & & & & \\
\hline Parthenopidae MacLeay, 1838 & & & & & \\
\hline Derilambrus angulifrons (Latreille, 1825) & & & $(+)$ & $(+)$ & $(+)$ \\
\hline Distolambrus maltzami (Miers, 1881) & $(+)$ & & & $(+)$ & $(+)$ \\
\hline Parthenopoides massena (Roux, 1830) & $(+)$ & $(+)$ & $(+)$ & $(+)$ & $(+)$ \\
\hline Spinolambrus macrochelos (Herbst, 1790) & & $(+)$ & $(+)^{1}$ & $(+)$ & $(+)$ \\
\hline Velolambrus expansus (Miers, 1879) & & & & $(+)$ & \\
\hline PILUMNOIDEA Samouelle, 1819 & & & & & \\
\hline Pilumnidae Samouelle, 1819 & & & & & \\
\hline Pilumnopeus africanus (De Man, 1902) & $(+)$ & & & & \\
\hline Pilumnus aestuarii Nardo, 1869 & & & & & $(+)$ \\
\hline Pilumnus hirtellus (Linnaeus, 1761) & $(+)$ & $(+)$ & $(+)$ & $(+)$ & $(+)$ \\
\hline Pilumnus inermis A. Milne-Edwards and Bouvier, 1894 & & $(+)$ & $(+)$ & $(+)$ & $(+)$ \\
\hline Pilumnus spinifer $\mathrm{H}$. Milne-Edwards, 1834 & $(+)$ & $(+)$ & $(+)$ & $(+)$ & $(+)$ \\
\hline Pilumnus villosissimus (Rafinesque, 1814) & & & $(+)$ & $(+)$ & $(+)$ \\
\hline Pilumnus sp. d'Udekem d'Acoz and Schubart (in prep.) & & & $(+)$ & & $(+)$ \\
\hline PORTUNOIDEA Rafinesque, 1815 & & & & & \\
\hline Carcinidae MacLeay, 1838 & & & & & \\
\hline Carcinus aestuarii Nardo, 1847 & & & & $(+)$ & $(+)$ \\
\hline Carcinus maenas (Linnaeus, 1758) & $(+)$ & $(+)$ & $(+)$ & $(+)$ & $(+)$ \\
\hline Portumnus latipes (Pennant, 1777) & $(+)$ & $(+)$ & $(+)$ & $(+)$ & $(+)$ \\
\hline Xaiva biguttata (Risso, 1816) & $(+)$ & & & $(+)$ & $(+)$ \\
\hline Geryonidae Colosi, 1923 & & & & & \\
\hline Chaceon affinis (A. Milne-Edwards and Bouvier, 1894) & $(+)$ & & & & \\
\hline Chaceon mediterraneus Manning and Holthuis, 1989 & & & & & $(+)$ \\
\hline Chaceon inglei Manning and Holthuis, 1989 & $(+)$ & & & & \\
\hline Geryon longipes A. Milne-Edwards, 1881 & $(+)$ & & $(+)$ & $(+)$ & $(+)$ \\
\hline Geryon trispinosus (Herbst, 1803) * & $(+)$ & $(+)$ & & & \\
\hline Pirimelidae Alcock, 1899 & & & & & \\
\hline Pirimela denticulata (Montagu, 1808) & $(+)$ & $(+)$ & $(+)$ & $(+)$ & $(+)$ \\
\hline Sirpus zariquieyi Gordon, 1953 & & $(+)$ & $(+)$ & $(+)$ & $(+)$ \\
\hline Polybiidae Ortmann, 1893 & & & & & \\
\hline Bathynectes longipes (Risso, 1816) & & $(+)$ & & $(+)$ & $(+)$ \\
\hline Bathynectes maravigna (Prestandrea, 1839) & $(+)$ & $(+)$ & $(+)$ & $(+)$ & $(+)$ \\
\hline Liocarcinus bolivari (Zariquiey Álvarez, 1948) & & & $(+)$ & & $(+)$ \\
\hline Liocarcinus corrugatus (Pennant, 1777) & $(+)$ & $(+)$ & $(+)$ & $(+)$ & $(+)$ \\
\hline Liocarcinus depurator (Linnaeus, 1758) & $(+)$ & $(+)$ & $(+)$ & $(+)$ & $(+)$ \\
\hline Liocarcinus holsatus (Fabricius, 1798) & $(+)$ & $(+)$ & & & \\
\hline Liocarcinus maculatus (Risso, 1827) & $(+)$ & & ? & $(+)$ & $(+)$ \\
\hline Liocarcinus marmoreus (Leach, 1814) & $(+)$ & $(+)$ & & $(+)$ & $(+)$ \\
\hline Liocarcinus mcleayi (Barnard, 1947) & & $(+)$ & $(+)$ & & \\
\hline Liocarcinus navigator (Herbst, 1794) & $(+)$ & $(+)$ & $(+)$ & $(+)$ & $(+)$ \\
\hline Liocarcinus pusillus (Leach, 1815) & $(+)$ & $(+)$ & $(+)$ & & \\
\hline Liocarcinus vernalis (Risso, 1816) & $(+)$ & $(+)$ & $(+)$ & $(+)$ & $(+)$ \\
\hline
\end{tabular}




\begin{tabular}{|c|c|c|c|c|c|}
\hline \multirow{2}{*}{ Taxa/Species } & \multicolumn{5}{|c|}{ Distribution } \\
\hline & G-GB & WP & GC & ALB & MED \\
\hline Liocarcinus zariquieyi Gordon, 1968 & & & & $(+)$ & $(+)$ \\
\hline Macropipus tuberculatus (Roux, 1830) & $(+)$ & $(+)$ & $(+)$ & $(+)$ & $(+)$ \\
\hline Necora puber (Linnaeus, 1767) & $(+)$ & $(+)$ & $(+)$ & $(+)$ & $(+)$ \\
\hline Polybius henslowii Leach, 1820 & $(+)$ & $(+)$ & $(+)$ & $(+)$ & $(+)$ \\
\hline \multicolumn{6}{|l|}{ Portunidae Rafinesque, 1815} \\
\hline Callinectes exasperatus (Gerstaecker, 1856) & & & $(+)$ & & \\
\hline Callinectes sapidus Rathbun, 1896 & $(+)$ & $(+)$ & $(+)$ & & $(+)$ \\
\hline Charybdis (Charybdis) feriata (Linnaeus, 1758) & & & & & $(+)$ \\
\hline Portunus (Portunus) hastatus (Linnaeus, 1767) & & & & $(+)$ & $(+)$ \\
\hline \multicolumn{6}{|l|}{ Thiidae Dana, 1852} \\
\hline Thia scutellata (Fabricius, 1793) & $(+)$ & $(+)$ & $(+)$ & $(+)$ & $(+)$ \\
\hline \multicolumn{6}{|l|}{ XANTHOIDEA MacLeay, 1838} \\
\hline \multicolumn{6}{|l|}{ Panopeidae Ortmann, 1893} \\
\hline Dyspanopeus sayi (Smith, 1869) & & & & & $(+)$ \\
\hline Panopeus africanus A. Milne-Edwards, 1867 & $(+)$ & $(+)$ & $(+)$ & & \\
\hline Rhithropanopeus harrisii (Gould, 1841) & & $(+)$ & $(+)$ & & \\
\hline \multicolumn{6}{|l|}{ Xanthidae MacLeay, 1838} \\
\hline Microcassiope minor (Dana, 1852) & & & & $(+)$ & $?$ \\
\hline Monodaeus couchii (Couch, 1851) & $(+)$ & & $(+)$ & $(+)$ & $(+)$ \\
\hline Paractaea monodi Guinot, 1969 & & & & $(+)$ & $(+)$ \\
\hline Xantho hydrophilus (Leach, 1814) & $(+)$ & $(+)$ & $(+)$ & $(+)$ & $(+)$ \\
\hline Xantho pilipes A. Milne-Edwards, 1867 & $(+)$ & $(+)$ & $(+)$ & $(+)$ & $(+)$ \\
\hline Xantho poressa (Olivi, 1792) & & $(+)$ & $(+)$ & $(+)$ & $(+)$ \\
\hline Xantho sexdentatus (Miers, 1881) & & & $(+)$ & & \\
\hline \multicolumn{6}{|l|}{ THORACOTREMATA Guinot, 1977} \\
\hline \multicolumn{6}{|l|}{ GRAPSOIDEA MacLeay, 1838} \\
\hline \multicolumn{6}{|l|}{ Grapsidae MacLeay, 1838} \\
\hline Pachygrapsus gracilis (Saussure, 1858) & $(+)$ & & & & \\
\hline Pachygrapsus marmoratus (Fabricius, 1787) & $(+)$ & $(+)$ & $(+)$ & $(+)$ & $(+)$ \\
\hline Pachygrapsus maurus (Lucas, 1846) & & & & $(+)$ & $(+)$ \\
\hline Pachygrapsus transversus (Gibbes, 1850) & & $(+)$ & $(+)$ & $(+)$ & $(+)$ \\
\hline Planes minutus (Linnaeus, 1758) & $(+)$ & $(+)$ & $(+)$ & $(+)$ & $(+)$ \\
\hline \multicolumn{6}{|l|}{ Plagusiidae Dana, 1851} \\
\hline Euchirograpsus liguricus H. Milne-Edwards, 1853 & & $(+)$ & $(+)$ & $(+)$ & $(+)$ \\
\hline \multicolumn{6}{|l|}{ Percnidae Števčić, 2005} \\
\hline Percnon gibbesi (H. Milne-Edwards, 1853) & & $(+)$ & & $(+)$ & $(+)$ \\
\hline \multicolumn{6}{|l|}{ Varunidae H. Milne-Edwards, 1853} \\
\hline Asthenognathus atlanticus Monod, 1933 & $(+)$ & & $(+)$ & $(+)$ & \\
\hline Brachynotus atlanticus Forest, 1957 & & & $(+)$ & $(+)$ & \\
\hline Brachynotus foresti Zariquiey Álvarez, 1968 & & & & & $(+)$ \\
\hline Brachynotus sexdentatus (Risso, 1827) & & & $(+)$ & $(+)$ & $(+)$ \\
\hline Eriocheir sinensis H. Milne-Edwards, 1853 & $(+)$ & $(+)$ & $(+)$ & & \\
\hline Hemigrapsus takanoi Asakura and Watanabe, 2005 & $(+)$ & & & & \\
\hline \multicolumn{6}{|l|}{ OCYPODOIDEA Rafinesque, 1815} \\
\hline \multicolumn{6}{|l|}{ Ocypodidae Rafinesque, 1815} \\
\hline Uca (Afruca) tangeri (Eydoux, 1835) & & $(+)$ & $(+)$ & & \\
\hline \multicolumn{6}{|l|}{ PINNOTHEROIDEA de Haan, 1833} \\
\hline \multicolumn{6}{|l|}{ Pinnotheridae de Haan, 1833} \\
\hline Afropinnotheres monodi Manning, 1993 & & & $(+)$ & & \\
\hline Nepinnotheres pinnotheres (Linnaeus, 1758) & $(+)$ & $(+)$ & $(+)$ & $(+)$ & $(+)$ \\
\hline Pinnotheres pisum (Linnaeus, 1767) & $(+)$ & $(+)$ & $(+)$ & $(+)$ & $(+)$ \\
\hline
\end{tabular}

\section{New species present in Iberian waters (since 1968)}

In this first group we have included 10 species new to science and reported in Iberian waters after the work of Zariquiey Álvarez (1968). Note that Monodaeus guinotae is considered as an invalid species and is not included in the checklist.

\section{Homologenus boucheti Guinot and Richer de Forges, 1995}

This deep-sea species was described to comprise the eastern Atlantic populations of Homologenus rostratus (A. Milne-Edwards 1880). In the Iberian Peninsula, it had only been reported (as H. rostratus) in the south of Portugal (García Raso 1996).

\section{Calappa tuerkayana Pastore, 1995}

This new species was described by Pastore (1995) from the Ionian Sea, and has been reported in the
Balearic Islands (García 2002, García and Corbera 2007) and Atlantic waters (d'Udekem d'Acoz 2001). The validity of $C$. tuerkayana was already questioned by Holthuis (2001), and new molecular evidence indicates that this species represents juvenile stages of Calappa granulata (Abelló and Palero in prep.). Therefore, C. tuerkayana should be excluded from the Iberian checklist in the near future.

\section{Pisa sp. Marco-Herrero et al. (in prep.)}

A megalopa stage collected in Balearic waters has been assigned to the genus Pisa using molecular data. However, the DNA sequence obtained does not correspond to any of the species of this genus found in Iberian waters (Marco-Herrero et al. in prep.). In addition, a small specimen of this genus, morphologically different to other known Iberian species, has been found in the Alboran Sea (García Raso et al. unpublished). 


\section{Macropodia deflexa Forest, 1978}

Forest described this Macropodia species as being closely related to $M$. czernjawskii, and its taxonomic validity has been questioned by d'Udekem d'Acoz (1999). The species has been reported in the Gulf of Biscay, Galicia, Portugal and the Gulf of Cádiz (Forest 1978, Fernández Cordeiro et al. 2006).

\section{Macropodia parva Van Noort and Adema, 1985}

D'Udekem d'Acoz (1999) suggested that this species could be attributed to juvenile stages of $M$. rostrata. Molecular evidence obtained by the authors support this assumption (Marco-Herrero et al. in prep.), so this species should also be excluded from the Iberian checklist in the near future.

\section{Maja brachydactyla Balss, 1922}

This species was established by the recognition of two distinct taxa within $M$. squinado sensu lato: $M$. squinado sensu stricto in Mediterranean waters and $M$. brachydactyla in Atlantic waters. The first hints given by Neumann (1998) were recently confirmed by DNA analyses (Sotelo et al. 2008). It should be pointed out that $M$. brachydactyla is also known to occur in the western Alboran Sea (Abelló et al. 2014).

\section{Pilumnus sp. d'Udekem d'Acoz and Schubart (in prep.)}

The taxonomy of Pilumnus is controversial, with no clear distinction between several species (d'Udekem d'Acoz 1999, Mavidis et al. 2009). Recent molecular studies on the European representatives of this genus have established six different operative taxonomic units, one of them corresponding to a yet undescribed species present in the Gulf of Cádiz (Oliveira-Biener et al. 2010, Schubart and Aichinger 2013).

8. Chaceon mediterraneus Manning and Holthuis, 1989

This deep-sea species is known so far from Mediterranean waters only. It has been reported in both the western (Cartes 1993) and eastern (Kitsos et al. 2005) Mediterranean basins.

\section{Chaceon inglei Manning and Holthuis, 1989}

This species was described based on a female specimen obtained during the Challenger expedition. It has been reported from Iceland, Scotland, southwest England, the Bay of Biscay, Madeira, and the Canary and Azores Islands (Manning and Holthuis 1989). In Iberian waters, it has been reported (as Geryon affinis) off Vigo (northwest Spain) (d'Udekem d'Acoz 1999, Araújo et al. 2009).

Invalid species:

1. Monodaeus guinotae Forest, 1976

This species has been recorded in southwest Portugal (d'Udekem d'Acoz 1999), southwest Spain, the Alboran Sea (García Raso 1996) and the Balearic Islands (García and Gracia 1996). The differences between this species and Monodaeus couchii are very small, and Mavidis et al. (2008) consider this species identical to $M$. couchii. Indeed, the recent molecular phylogeny study by Reuschel and Schubart (2006) in- dicates that $M$. guinotae should be considered a synonym of $M$. couchii.

\section{Species reported after 1968}

This second group includes 17 species that were known by 1968 but had not been reported in Iberian waters. It also includes one invalid species:

1. Cymonomus normani Lankaster, 1903

This eastern Atlantic species was reported in Portuguese waters by Türkay (1976).

\section{Calappa pelii Herklots, 1851}

This is a West African species collected once in the Chafarinas Islands (Silvestre, identification confirmed by Galil et al. 2002)

\section{Cryptosoma cristatum Brullé, 1837}

This species has been reported from the Macaronesian archipelagos (Madeira, Azores, Canarias, Cape Verde), and also in Málaga and Alboran Sea by García Raso (1993). There is an unpublished photography of a specimen collected in Algarve (Portugal) in 2008 (M.M. Rufino pers. comm.).

\section{Ethusina talismani A. Milne-Edwards} and Bouvier, 1897

This is a West African species, reported from South Portugal by García Raso (1996).

\section{Paragalene longicrura (Nardo, 1869)}

This is a rare species with a wide distribution, from the Aegean Sea (eastern Mediterranean) to Madeira (eastern Atlantic), reported in the Balearic Islands by García Socias (1985) and Gili and Macpherson (1987).

\section{Pisa carinimana Miers, 1879}

This species is known to occur from the Canary Islands (topotypic locality) to Angola, and was recently observed for the first time in Madeira (Ramalhosa et al. 2014). It was collected in Melilla (Mediterranean North Africa) by Zariquiey Álvarez (1968) and for the first time in the Alboran Sea by García Raso (1981, 1984), and in the Gulf of Cádiz by González-Gordillo et al. (1990).

\section{Velolambrus expansus (Miers, 1879)}

Also reported as Parthenope expansa, this species is distributed from the eastern Atlantic to the eastern Mediterranean. It was collected from the Alboran Sea by García Raso $(1989,1996)$.

8. Chaceon affinis (A. Milne-Edwards and Bouvier, 1894) This eastern Atlantic species was found off Galicia (Northwestern Spain) by González Gurriarán and Méndez (1986).

\section{Geryon trispinosus (Herbst, 1803)}

This species, very similar to the northeastern Atlantic G. longipes, has been captured off Galicia (Urgorri et al. 1990) and Portugal (Vilela 1936, Türkay 1976). 


\section{Liocarcinus maculatus (Risso, 1827)}

This species has been confounded with $L$. pusillus and L. zariquieyi, but Froglia and Manning (1982) summarized their distinctive morphological traits. It is mainly present in the Mediterranean Sea, with some occurrences in the eastern Atlantic. It has been collected in the Alboran Sea (García Raso 1984, 1996) and along the Catalan coast (Abelló et al. 1988, 2002).

\section{Liocarcinus mcleayi (Barnard, 1947)}

A synonym of Xaiva mcleayi and Polybius mcleayi. It was recorded in Portugal (as Macropipus zariquieyi) by Neves (1978), and in the South of Spain (Barbate, Cádiz) by García Raso and Manjón Cabeza (1996).

\section{Paractaea monodi Guinot, 1969}

This species was reported from North Africa (Melilla) as Actaea rufopunctata (Zariquiey, 1968). Specimens (as Paractaea rufopunctata) were caught in the Alboran Sea (García Raso and Barrajón 1983, García Raso 1990). It is also known from the Balearic Islands (Corbera et al. 1993).

\section{Microcassiope minor (Dana, 1852)}

An Atlantic species that has also been reported from Almeria and the Alboran Sea (García Raso and López de la Rosa 1992).

\section{Xantho sexdentatus (Miers, 1881)}

This tropical and subtropical Atlantic species is distributed from Senegal to the western Sahara (d'Udekem d'Acoz 1999), and the closest records to the Iberian Peninsula so far correspond to the Azores and Canary Islands (Fransen 1991). A specimen, identified by DNA barcoding in the context of the MEGALOPADN project as X. sexdentatus, has been collected in Rota (Cádiz). This constitutes a new report for the Iberian fauna.

\section{Brachynotus atlanticus Forest, 1957}

This western Atlantic species has been reported for Iberian waters in the Gulf of Cádiz (García Raso 1985, González-Gordillo et al. 1990) and the Alboran Sea (García Raso 1984, 1985).

\section{Afropinnotheres monodi Manning, 1993}

This African pinnotherid was recently reported for the first time in the Gulf of Cádiz by Subida et al. (2011), which also constituted the first record in European waters. This was the third report for this species worldwide. Although it is probably a case of natural range expansion, an introduction by fouling should not be discarded, given that the mussel Mytilus galloprovincialis is one of its main hosts (Drake et al. 2014).

Invalid species:

1. Brachynothus gemmellaroi (Rizza, 1839)

The westernmost record for this Mediterranean endemic species was reported as B. gemmellari in the Ebro Delta (Guerao et al. 1995). Although it is still considered a valid species (e.g. WoRMS), initial DNA evidence suggests that $B$. gemmellari should be con- sidered an ecophenotype of Brachynotus sexdentatus (Schubart et al. 2001).

\section{Newly introduced alien species}

Human introduction of alien/allochthonous species has become an important biodiversity concern (Zenetos et al. 2010). Crab species are not an exception and up to ten alien species have recently been found in Iberian waters, namely: Hemigrapsus takanoi, Eriocheir sinensis, Percnon gibbesi, Dyspanopeus sayi, Rhithropanopeus harrisii, Callinectes sapidus, Charybdis feriata, Callinectes exasperatus, Pachygrapsus gracilis and Pilumnopeus africanus (Cuesta Mariscal et al. 1991, Abelló and Hispano 2006, García-de-Lomas et al. 2010, Castejón and Guerao 2013, Marco-Herrero et al. 2013b, Almon et al. 2014, Cuesta et al. 2015). The first six species from this list show established populations in Iberian waters:

1. Hemigrapsus takanoi Asakura and Watanabe, 2005

The first European records of this varunid crab from Asia were identified as Hemigrapsus penicillatus (de Haan, 1835) since H. takanoi was not described at that time. Asakura and Watanabe (2005) described $H$. takanoi as a new species and differentiated it from $H$. penicillatus. In the Iberian coast, $H$. takanoi was first reported from Laredo (Gulf of Biscay) (Noël et al. 1997), and it is now well established in several localities of this region (Dauvin et al. 2009).

\section{Eriocheir sinensis H. Milne-Edwards, 1853}

The Chinese mitten crab is native to the east coast of China, from Hong Kong to North Korea. In the Iberian Peninsula, E. sinensis has been established in the Guadalquivir Estuary, SW Iberian Peninsula (Garcia-deLomas et al. 2010). It has been reported from the Tagus estuary (Cabral and Costa 1999) and Zumaia (Gulf of Biscay) (Martínez and Adarraga 2006), but there are no data about stable populations in these localities.

\section{Rhithropanopeus harrisii (Gould, 1841)}

The Harris mud crab is native to the Atlantic coast of North America, from the southern Gulf of Saint Lawrence (Canada) to the Gulf of Mexico. R. harrisii has been established in the Guadalquivir and Guadalete estuaries, SW Iberian Peninsula (Cuesta Mariscal et al. 1991, Rodríguez et al. unpublished data) and it was also reported in the Mondego estuary (Portugal) (Gonçalves et al. 1995).

\section{Dyspanopeus sayi (Smith, 1869)}

Say's mud crab is native to the northwestern Atlantic Ocean from Canada to Florida. This species has been established in the Ebro Delta, NE Iberian Peninsula (Schubart et al. 2012, Marco-Herrero et al. 2013b).

\section{Percnon gibbesi (H. Milne-Edwards, 1853)}

Zariquiey Álvarez (1968) reported Percnon planissimum (Herbst, 1804) as being a species very rarely present in Portuguese waters, but these records have not been confirmed. Instead, the Atlantic species Perc- 
non gibbesi has been recently recorded in different localities throughout the Mediterranean (see Katsanevakis et al. 2011). In the Iberian Peninsula, the species has been reported in the Balearic Islands (García and Reviriego 2000, Müller 2001), Alicante (Acosta 2003), the Columbretes Islands and Barcelona (Abelló et al. 2003), Murcia (Félix-Hackradt et al. 2010), Almeria (Junta de Andalucía, GEOBIO 2010), Valencia (Palero unpublished data) and Granada (de la Roza, personal comm.). Megalopa stages and early juvenile specimens have recently been collected from Cullera (Valencia). Citizen science reports, mediated through the website "Observadores del Mar", show that the species is now widely reported along the Mediterranean coasts from Cape Palos to Catalonia, as well as in the Balearic Islands. It is not yet clear whether this Mediterranean expansion from the Atlantic is a natural process or was mediated by human activities (accidental transport in ballast water or specimens released from pet trade).

\section{Callinectes sapidus Rathbun, 1896}

Some adult specimens of the American blue crab were recently captured in the Ebro Delta, but more data are needed to determine whether this species is definitely established. The species can be considered rare in other areas of the Iberian Peninsula (Castejón and Guerao 2013), although a recent report of one ovigerous female from the Sado estuary might indicate the establishment of a small population (Ribeiro and Verissimo 2014).

Some casual reports are known for the remaining alien species of this checklist, including a single adult female of the Indo-Pacific portunid Charybdis feriata caught in Barcelona (Abelló and Hispano 2006), one male specimen of Callinectes exasperatus collected in the Bay of Cádiz (Cuesta et al. 2015), and four specimens of Pilumnopeus africanus and two specimens of Pachygrapsus gracilis collected in Galicia (NW Spain) by Almon et al. (2014).

When species native from distant localities are reported within Iberian waters, there is little doubt that they were introduced through human activities (intentional or accidentally). However, this is not necessarily the case for species native from nearby areas in West and North Africa which have been recently found in the Alboran Sea and Gulf of Cádiz (Calappa pelii, Cryptosoma cristatum, and Afropinnotheres monodi). These were not considered as introduced species in the present account, but this hypothesis cannot be discarded.

\section{Systematic remarks}

The scientific names of some species considered by Zariquiey Álvarez (1968) have changed due to new systematic studies or synonymizations, and these are listed in Table 2. Other systematic changes refer to higher taxonomic levels, and these will be addressed here.

The first main change in the systematics of brachyuran crabs after 1968 was the proposal of new sections and subsections by Guinot (1977, 1978, 1979), de Saint Laurent (1979, 1980), and Guinot and Bouchard
Table 2. - Previous and current names of brachyuran species present in the Iberian Peninsula renamed since Zariquiey Álvarez (1968), listed by alphabetical order.

\begin{tabular}{ll}
\hline \multicolumn{1}{c}{ Previous names } & \multicolumn{1}{c}{$\begin{array}{c}\text { Current names } \\
\text { (as in } \text { ing } \text { et al. 2008) }\end{array}$} \\
\hline Achaeus gordonae Álvarez 1968) & Achaeus gracilis \\
Actaea rufopunctata & Paractaea monodi \\
Bathynectes superbus & Bathynectes maravigna \\
Carcinus mediterraneus & Carcinus aestuarii \\
Dicranodromia mayheuxi & Dicranodromia mahieuxii \\
Ebalia cranchi & Ebalia cranchii \\
Ebalia edwardsi & Ebalia edwardsii \\
Heterocrypta maltzani & Distolambrus maltzami \\
Macropipus arcuatus & Liocarcinus navigator \\
Macropipus bolivari & Liocarcinus bolivari \\
Macropipus corrugatus & Liocarcinus corrugatus \\
Macropipus depurator & Liocarcinus depurator \\
Macropipus holsatus & Liocarcinus holsatus \\
Macropipus marmoreus & Liocarcinus marmoreus \\
Macropipus puber & Necora puber \\
Macropipus pusillus & Liocarcinus pusillus \\
Macropipus vernalis & Liocarcinus vernalis \\
Macropipus zariquieyi & Liocarcinus zariquieyi \\
Maja verrucosa & Maja crispata \\
Medaeus couchi & Monodaeus couchii \\
Parthenope angulifrons & Derilambrus angulifrons \\
Parthenope macrochelos & Spinolambrus macrochelos \\
Parthenope massena & Parthenopoides massena \\
Pinnotheres pinnotheres & Nepinnotheres pinnotheres \\
Pisa corallina & Pisa hirticornis \\
Xantho incisus granulicarpus & Xantho hydrophilus \\
Xantho incisus incisus & Xantho hydrophilus \\
\hline &
\end{tabular}

(1998). Based on the male and female genital apertures, these authors separated brachyuran crabs into Dromiacea and Eubrachyura, or the subsections Podotremata, Heterotremata and Thoracotremata. Morphological and molecular analyses do not reveal monophyly within Podotremata, so the most recent classifications divide it into three sections: Dromiacea, Cyclodorippoidea and Raninoida (De Grave et al. 2009). According to these changes, the old term Reptantia (present in Zariquiey Álvarez 1968) was removed from the classification. Considering just those superfamilies present in Iberian waters, most changes correspond to splits of old taxa into several new superfamilies. For example, the superfamily Corystoidea (which comprised the families Atelecyclidae, Cancridae, Corystidae, Pirimelidae and Thiidae) now comprises Corystidae only, while Atelecyclidae and Cancridae have been placed in the new superfamily Cancroidea, and Pirimelidae and Thiidae have been relocated within the Portunoidea (Spiridonov et al. 2014). All changes at the superfamily level are listed in Table 3, including new family composition.

Some of the most important changes affect the assignment of genera to new families, which cannot be appreciated in Table 3. For example, the former Majidae family suffered important changes due to its elevation into a superfamily (Majoidea) and the elevation to family level of previous subfamilies: Majidae, Epialtidae, and Inachidae. Some authors have raised Pisidae as well (Hendrickx 1995), but we followed here the more conservative classification of $\mathrm{Ng}$ et al. (2008) considering Pisiinae as a subfamily of Epialtidae. A recent study based on larval morphology and DNA did not support a clear separation between epialtid and pisid crabs (Hultgren and Stachowitz 2008). Neverthe- 
Table 3. - Previous and current names (and family composition) of the superfamilies of brachyuran crabs present in the Iberian Peninsula, listed by systematic order.

\begin{tabular}{|c|c|c|c|}
\hline \multirow{2}{*}{\multicolumn{2}{|c|}{$\begin{array}{c}\text { Previous names } \\
\text { (as in Zariquiey Álvarez 1968) } \\
\text { Family }\end{array}$}} & \multicolumn{2}{|c|}{$\begin{array}{l}\text { Current names } \\
\text { (as in Ng et al. } 2008 \text { and Spiridonov et al. 2014) }\end{array}$} \\
\hline & & Superfamily & Family \\
\hline \multirow[t]{4}{*}{ Dromiacea } & Dromiidae & Homolodromioidea & Homolodromiidae \\
\hline & & Dromioidea & Dromiidae \\
\hline & Homolidae & Homoloidea & Homolidae \\
\hline & Latreillidae & & Latreillidae \\
\hline \multirow[t]{5}{*}{ Oxystomata } & Dorippidae & Dorippoidea & Dorippidae \\
\hline & & & Ethusidae \\
\hline & & Cyclodorippoidea & Cymonomidae \\
\hline & Calappidae & Calappoidea & Calappidae \\
\hline & Leucosiidae & Leucosioidea & Leucosiidae \\
\hline \multirow[t]{5}{*}{ Corystoidea } & Corystidae & Corystoidea & Corystidae \\
\hline & Atelecyclidae & Cancroidea & Atelecyclidae \\
\hline & Canceridae & & Cancridae \\
\hline & Pirimelidae* & & \\
\hline & Thiidae* & & \\
\hline \multirow[t]{19}{*}{ Brachyryncha } & Goneplacidae & Goneplacoidea & Goneplacidae \\
\hline & & & Progeryonidae \\
\hline & Grapsidae & Grapsoidea & Grapsidae \\
\hline & & & Percnidae \\
\hline & & & Plagusiidae \\
\hline & & & Varunidae \\
\hline & Ocypodidae & Ocypodoidea & Ocypodidae \\
\hline & Palicidae & Palicoidea & Palicidae \\
\hline & Pinnotheridae & Pinnotheroidea & Pinnotheridae \\
\hline & Portunidae & Portunoidea & Carcinidae \\
\hline & & & Portunidae \\
\hline & & & Pirimelidae* \\
\hline & & & Polybiidae \\
\hline & & & Thiidae* \\
\hline & & & Geryonidae** \\
\hline & Xanthidae & Pilumnoidea & Pilumnidae \\
\hline & & Xanthoidea & Xanthidae \\
\hline & & & Panopeidae \\
\hline & & Eriphioidea & Eriphiidae \\
\hline \multirow{5}{*}{ Oxyrhyncha } & Majidae & Majoidea & Majidae \\
\hline & & & Epialtiidae \\
\hline & & & Inachidae \\
\hline & & & Oregoniidae \\
\hline & Parthenopidae & Parthenopoidea & Parthenopidae \\
\hline
\end{tabular}

* Pirimelidae and Thiidae have been relocated in Portunoidea according to Spiridonov et al. (2014)

**Geryonids were considered to belong to Xanthidae in Zariquiey Álvarez (1968)

less, larval morphology and DNA data suggest that Ergasticus clouei should be moved from Inachidae to Oregoniidae, a family that was not present in Iberian waters (Marco-Herrero et al. 2013a).

Within the Grapsoidea superfamily, the former Grapsidae is now restricted to the previous subfamily Grapsinae, while other subfamilies that acquired familial level (e.g. Varunidae, Plagusiidae and Percnidae) are also present in Iberian waters (see Schubart et al. 2002, Schubart and Cuesta 2010). Some genera and species have also changed their placement, such as Euchirograpsus that was considered a Varuninae and is now within the Plagusiidae.

The superfamily Portunoidea is still under discussion. Geryonid crabs, which were previously considered as part of Xanthidae, now belong to Geryonidae. Schubart and Reuschel (2009) proposed a new taxonomy based on molecular evidence for the Pirimelidae (traditionally placed in Cancroidea), Polybiidae, Carcinidae and Thiidae (according to $\mathrm{Ng}$ et al. 2008, but currently in its own superfamily Thioidea), and these changes obtained further support from Spiridonov et al. (2014). Several portunoid genera are currently under study and new modifications are expected.
The Parthenopidae family has also experienced strong changes after the work of Tan and $\mathrm{Ng}$ (2007). In the case of Iberian species, all generic names have been modified (new combinations) and the three species of Parthenope are now considered as one species of Spinolambrus and the monotypic genera Derilambrus and Parthenopoides. The former parthenopid genus Heterocrypta, a monotypic genus also found in Iberian waters, is now named Distolambrus.

Another important change affects the systematic position of Asthenognathus atlanticus, a former pinnotherid crab that is now considered a member of the subfamily Asthenognathinae (Grapsoidea: Varunidae). This modification, based on larval and molecular evidences provided by Cuesta et al. (2005), was already included in $\mathrm{Ng}$ et al. (2008).

Within the Ocypodidae, Spivak and Cuesta (2009) proposed to elevate the subgenus Afruca to genus level, based on larval morphology and supported by previous phylogenies of the genus Uca, and then named the species inhabiting the southwest of the Iberian Peninsula as Afruca tangeri. However, this proposal has not been followed in later studies and Afruca tangeri is maintained in this checklist as Uca (Afruca) tangeri. 
Finally, morphological studies by Forest (1978) and García Raso et al. (1987) have questioned the validity of Macropodia longipes and considered its possible synonymy with Macropodia tenuirostris. Studying the larval development of both species, Guerao and Abelló (1997) also mentioned that "... the two species are closely related phylogenetically". Both species are maintained as reported in Zariquiey Álvarez (1968), but their taxonomic status will be clarified with ongoing molecular phylogenetics research.

\section{The Iberian carcinofauna: future changes}

Further modifications are still ongoing in brachyuran systematics, so changes in the Iberian carcinofauna are expected to come in the near future. The improvements on the application of molecular tools and phylogenetic inference methods and the use of larval morphology are expected to bring further changes in the systematics of brachyuran crabs. These will have an impact at several taxonomic levels, from species to superfamilies. For example, preliminary studies carried out by our team on the molecular phylogeny of the Inachidae family, or some genera like Ebalia, Liocarcinus and Pisa, point to the presence of synonymy, the necessity to split some taxa into new species, and the erection of new genera. The validity of some species is currently questioned, such as the case of Calappa tuerkayana (possible synonym of Calappa granulata), Geryon trispinosus (possible synonym of Geryon longipes), Macropodia parva (as synonym of Macropodia rostrata) and Macropodia longipes (as synonym of Macropodia tenuirostris).

Although descriptions of crab species new to science are not expected to occur at a significant rate, an increase on the number of taxa in the Iberian Peninsula will surely result from the human introduction of alien species, as well as the natural expansion of species from West and North Africa and the eastern Mediterranean. Likely candidates to expand the checklist include Pinnotheres pectunculi (presumably present in the Iberian Peninsula as a native species; d'Udekem d'Acoz pers. comm.), Hemigrapsus sanguineus, Portunus sayi and maybe Potamon ibericum (introduced to the Cagne river in southern France between 1975 and 1983 [Noël and Guinot, 1983]). Species of warmer waters will expand their geographic range through "tropicalization" and climate change will favour the expansion of thermophilic species (Verges et al. 2014). Although not all of their predictions have been fulfilled, the likely arrival of alien species was already mentioned by Almaça (1985) and García Raso et al. (1987), and new species are expected to arrive in the near future.

\section{ACKNOWLEDGEMENTS}

Thanks are due to Félix Pérez (ICM), Enrique Macpherson (CEAB), Paul Clark (NHM), Laure Corbari (MNHN), Paula Martin-Lefevre (MNHN) and to J.-C. Dauvin (Univ. Caen Basse-Normandie) for facilitating access to key specimens to complete the present study. Thanks are also due to Cedric d'Udekem d'Acoz, Pierre Nöel and Carlo Froglia for criticism and suggestions that clearly improved the manuscript. This research was carried out within the framework of the MEGALOPADN project (CGL2009-11225) funded by the "Ministerio de Economía y Competividad (MINECO)" Spanish Plan R+D+I and FEDER. MarcoHerrero acknowledges the pre-doctoral FPI Fellowship (BES-2010-033297), and the present study was carried out as part of her PhD Thesis.

\section{REFERENCES}

Abelló P., Hispano C. 2006. The capture of the Indo-Pacific crab Charybdis feriata (Linnaeus, 1758) (Brachyura: Portunidae) in the Mediterranean Sea. BioInvasions Rec. 1(1): 13-16.

Abelló P., Valladares F. J., Castellón, A. 1988. Analysis of the structure of decapod crustacean assemblages off the Catalan coast (North-West Mediterranean). Mar. Biol. 98: 39-49. http://dx.doi.org/10.1007/BF00392657

Abelló P., Carbonell, A., Torres P. 2002. Biogeography of epibenthic crustaceans on the shelf and upper slope off the Iberian Peninsula Mediterranean coasts: implications for the establishment of natural management areas. Sci. Mar. 66S2: 183-198.

Abelló P., Visauta E., Bucci A., et al. 2003. Noves dades sobre l'expansió del cranc Percnon gibbesi (Brachyura: Grapsidae) a la Mediterrània occidental. Boll. Soc. Hist. Nat. Balears 46: 73-77.

Abelló P., Guerao G., Salmerón F., et al. 2014. Maja brachydactyla (Brachyura, Majidae) in the western Mediterranean. Mar. Biodiver. Rec. 7: e77.

Acosta R. 2003. Cita de cangrejo araña en aguas de Alicante. Quercus 212: 37.

Almaça C. 1985. Consideraçoes zoogeograficas sobre a fauna ibérica de Brachyura (Crustacea, Decapoda). Arq. Mus. Boc. (Séria A) Vol. III, 4: 51-68.

Almon B., Pérez J, Souto J., et al. 2014. ALIEN SPECIES An example of introduction of exotic species by fouling. Abstract XVIII SIEBM: 90.

Araújo R., Biscoito M., Santana J.I., et al. 2009. First record of the deep-sea red crab Chaceon inglei (Decapoda: Geryonidae) from Madeira and the Canary Islands (northeastern Atlantic Ocean). Bocagiana 230: 1-6.

Asakura A., Watanabe S. 2005. Hemigrapsus takanoi, new species, a sibling species of the common Japanese intertidal crab H. penicillatus (Decapoda: Brachyura: Grapsoidea). J. Crustac. Biol. 25: 279-292. http://dx.doi.org/10.1651/C-2514

Bowman T.E., Abele L.G. 1982. Classification of the recent Crustacea. Biol. Crustac. 1: 1-27.

Cabral H.N., Costa M.J. 1999. On the occurrence of the Chinese mitten crab Eriocheir sinensis in Portugal (Decapoda, Brachyura). Crustaceana 72: 55-58. http://dx.doi.org/10.1163/156854099502853

Cartes J.E. 1993. Deep-sea decapod fauna of the western Mediterranean: bathymetric distribution and biogeographic aspects. Crustaceana 65: 29-40. http://dx.doi.org/10.1163/156854093X00342

Castejón D., Guerao G. 2013. A new record of the American blue crab, Callinectes sapidus Rathbun, 1896 (Decapoda: Brachyura: Portunidae), from the Mediterranean coast of the Iberian Peninsula. BioInvasions Rec. 2(2): 141-143. http://dx.doi.org/10.3391/bir.2013.2.2.08

Corbera J., Ballesteros E., Garcia L. 1993. XXXVII. Els crustacis decàpodes. In: Alcover J.A., Ballesteros E., Fornós J.J. (eds) Història Natural de l'Arxipèlag de Cabrera. Palma de Mallorca: CSIC- Edit. Moll, pp. 579-587.

Cuesta Mariscal J. A., García Raso J.E., González Gordillo I. 1991. Primera cita de Rhithropanopeus harrisii (Crustacea Decapoda, Brachyura, Xanthidae) en la Península Ibérica. Bol. IEO 7(2):149-153.

Cuesta J.A., Schubart, C.D., Felder, D.L. 2005. Systematic position of the Asthenognathinae Stimpson, 1858 and Pseudopinnixa carinata Ortman (Decapoda, Brachyura): new findings from larval and DNA comparisons. Abstracts 6th ICC: 127. 
Cuesta J.A., Drake P., Arias A.M. 2015. First record of the blue crab Callinectes exasperatus (Decapoda, Brachyura, Portunidae) for European waters. Mar. Biodiver. Rec. 8: e36. http://dx.doi.org/10.1017/S175526721500010X

Dauvin J.C., Tous Rius A., Ruellet T. 2009. Recent expansion of two invasive crabs species Hemigrapsus sanguineus (de Haan, 1835 ) and $H$. takanoi Asakura and Watanabe 2005 along the Opal Coast, France. Aquat. Invasions 4(3): 451-465. http://dx.doi.org/10.3391/ai.2009.4.3.3

De Grave S., Pentcheff N., D., Ahyong S.T. 2009. A classification of living and fossil genera of decapod crustaceans. Raff. Bull. Zool. Suppl. 21: 1-109.

De Saint Laurent M. 1979. Vers une nouvelle classification des Crustacés Décapodes Reptantia. Bulletin de I'Office National des Pêches Republique Tunisienne, Ministere de UA agriculture 3: 15-31.

De Saint Laurent 1980. On the classification and phylogeny of Crustacea Deacopda Brachyura-Heterotremata and Thoracotremata Guinot, 1977. C. R. Hebd. Acad. Scie. Ser. D 290(20): 1317-1320.

Drake P., Marco-Herrero E., Subida M.D., et al. 2014. Host use pattern of the pea crab Afropinnotheres monodi: potential effects on its reproductive success and geographical expansion. Mar. Ecol. Prog. Ser. 498: 203-215. http://dx.doi.org/10.3354/meps 10623

D'Udekem d'Acoz C. 1999. Inventaire et distribution des crustacés décapodes de l'Atlantique nord-oriental, de la Méditerranée et des eaux continentales adjacentes au nord de $25^{\circ} \mathrm{N}$. Paris: $\mathrm{Mu}-$ séum National d'Histoire Naturelle. Patrimoines Naturels 40: 383 pp.

D'Udekem d'Acoz C. 2001. Remarks on the genera Balssia Kemp, 1922 and Acanthonyx Latreille, 1828 in the Azores, and first record of Calappa tuerkayana Pastore, 1995 (Crustacea, Decapoda) in the Atlantic Ocean. Arquipel. Life Mar. Sci. 18-A: 53-59.

Félix-Hackradt F., Hackradt C., Treviño-Otón J., et al. 2010. Continued expansion of Percnon gibbesi (Crustacea: Decapoda: Plagusiidae) into western Mediterranean waters. Mar. Biodiver. Rec. 3: e22. http://dx.doi.org/10.1017/S1755267210000175

Fernández Cordeiro A., Pino Pérez J.J., Pino Pérez R. 2006. Nuevos datos sobre la distribución de algunos crustáceos decápodos (Crustacea, Decapoda, Brachyura) para las costas de Galicia. NACC (Bioloxía) 15: 89-93.

Forest J. 1978. Le genre Macropodia Leach dans les eaux atlantiques européennes (Crustacea Brachyura Majidae) Cah. Biol. Mar 19: 323-342.

Fransen C.H.J.M. 1991. Preliminary report on Crustacea collected in the eastern part of the North Atlantic during the CANCAP and Mauritania expeditions of the former Rijksmuseum van Natuurlijke Historie, Leiden. Nationaal Naturhistorisch Museum, Leiden, pp 1-200.

Froglia C., Manning R.B. 1982. Notes on Liocarcinus pusillus (Leach) and related species. Quad. Lab. Tecnol. Pesca 3(2-5): 257-266.

Galil B., Froglia C., Noël P. 2002. CIESM Atlas of Exotic species in the Mediterranean. Vol. 2. Crustaceans: decapods and stomatopods. Briand F. Ediciones CIESM Publishers, Monaco, 192 pp.

García Ll. 2002. Presencia de Calappa tuerkayana Pastore, 1995 (Decapoda: Brachyura: Calappidae) en el Mediterráneo Occidental. Boll. Soc. Hist. Nat. Balears 45: 217-223.

García Ll., Corbera J. 2007. Els crancs de les Balears. Inca: Edicions Documenta Balear, 104 pp.

García L1., Gracia, F. 1996. Sobre algunes espècies de crustacis decàpodes interessants de les illes Balears (Crustacea, Decapoda). Boll. Soc. Hist. Nat. Balears 39: 177-186.

García L1., Reviriego B. 2000. Presència del cranc subtropical Percnon gibbesi (H. Milne Edwards, 1853) (Crustacea, Decapoda, Grapsidae) a les Illes Balears. Primera cita a la Mediterrània occidental. Boll. Soc. Hist. Nat. Balears 43: 81-89.

García-de-Lomas J., Dana E.D., López-Santiago J., et al. 2010. Management of the Chinese mitten crab, Eriocheir sinensis $(\mathrm{H}$. Milne Edwards, 1853) in the Guadalquivir Estuary (Southern Spain). Aquat. Invasions 5(3): 323-330. http://dx.doi.org/10.3391/ai.2010.5.3.11

García Raso J.E. 1981. Presencia de Pisa carinimana Miers, 1879 (Crustacea, Decapoda) en las costas de la Península Ibérica. Arq. Mus. Bocage, ser. B 1(15): 173-179.

García Raso J. E. 1984. Brachyura of the coast of Southern Spain. Spixiana 7(2): 105-113
García Raso J.E. 1985. Presencia de una población de Brachynotus atlanticus Forest, 1957 (Crustacea, Decapoda, Brachyura: Grapsidae) en el sur de la Península Ibérica. Bol. Soc. Port. Entomol. Supl. 19-26.

García Raso J.E. 1989. Resultados de la II Campaña del Instituto Español de Oceanografía para la exploración de los fondos de Coral Rojo en el mar de Alborán. Bol. IEO 5(2): 27-36.

García Raso J.E. 1990. Study of a Crustacea Decapoda Taxocoenosis of Posidonia oceanica beds from the Southern of Spain. P.S.Z.N.I. Mar. Ecol. 11(4): 309-326. http://dx.doi.org/10.1111/j.1439-0485.1990.tb00386.x

García Raso J.E. 1993. New record of other African species of Crustacea Decapoda, Cycloes cristata (Brullé), from European and Mediterranean waters. Bios 1(1): 215-221.

García Raso J.E. 1996. Crustacea Decapoda (Excl, Sergestidae) from Ibero-Moroccan waters. Results of BALGIM-84 Expedition. Bull. Mar. Sci. 58(3): 730-752.

García Raso J.E., Barrajón A. 1983. Contribución al conocimiento de los Xanthidae MacLeay (Crustacea, Decapoda, Brachyura) del Sur de España. Mon. Trab. Zool. Málaga (1981-1982) 3-4: 3-14.

García Raso J.E., López de la Rosa I. 1992. Presencia de Microcassiope minor (Dana) (Crustacea: Decapoda: Xanthidae) en aguas europeas del Mediterráneo Occidental. Cah. Biol. Mar. 33: $75-81$

García Raso J.E., Manjón-Cabeza M.E. 1996. New record of Liocarcinus mcleayi (Barnard, 1947), new combination, (Decapoda, Barchyura, Portunidae) from South Europe. Crustaceana 69(1): 84-93. http://dx.doi.org/10.1163/156854096X00114

García Raso J.E., González-Gurriarán E., Sardá F. 1987. Estudio comparativo de la fauna de crustáceos decápodos braquiuros de tres áreas de la Península Ibérica (Galicia, Málaga, Cataluña). Inv. Pesqu. 51(Supl. 1): 43-55.

García Socias Ll. 1985. Sobre la presencia en aguas de Mallorca de Paragalene longicrura (Nardo, 1868) y Euchirograpsus liguricus H. Milne Edwards, 1853 (Crustacea, Decapoda, Brachyura). Boll. Soc. Hist. Nat. Balears 29: 123-127.

Gili J.M., Macpherson E. 1987. Crustáceos Decápodos capturados en cuevas submarinas del litoral Balear. Inv. Pesq. 51:285-291.

Gonçalves F., Ribeiro R., Soares A.M. 1995. Rhithropanopeus harrisii (Gould) An American crab in the estuary of the Mondego River, Portugal. J. Crustac. Biol. 15: 756-762. http://dx.doi.org/10.2307/1548824

González-Gordillo J.I., Cuesta Mariscal J.A., Pablos F. 1990. Adiciones al conocimeinto de los crustaceos decapodos de las zonas mediolitorales e infralitorales de las costas suratlanticas andaluzas (Suroeste Espafia). I. Brachyura. Cah. Biol. Mar 31: 417-429.

González-Gurriarán E., Méndez M. 1986. Crustáceos Decápodos das costas de Galicia. 1. Brachyura. Cuadernos da Área de Ciencias Biolóxicas, Seminario de Estudos Galegos, Vol $2\left(2^{\mathrm{a}}\right.$ edición). O Castro-Sada, A Coruña. Ed. Do Castro, pp. 1-242.

Guerao G., Abelló P. 1997. Larval development of the spider crab Macropodia longipes Brachyura: Majidae: Inachinae. J. Crustac. Biol. 173: 459-471. http://dx.doi.org/10.2307/1549440

Guerao, G., Cuesta, J.A., Abelló, P., et al. 1995. Larval development of Brachynotus gemmellari (Rizza, 1839) (Brachyura, Grapsidae) reared under laboratory conditions. J. Plank. Res. 17: 1143-1161. http://dx.doi.org/10.1093/plankt/17.5.1143

Guinot D. 1977. Propositions pour une nouvelle classification des Crustacés Décapodes Brachyoures. C. R. hebd. Séanc. Acad. Sci., Paris, n. sér. A Zool. 285: 1049-1052.

Guinot D. 1978. Principes d'une classification évolutive des Crustacés Décapodes Brachyoures. Bull. Biol. France Belgique, N.S. 112 (3): 211-292.

Guinot D. 1979. Données nouvelles sur la morphologie, la phylogenèse et la taxonomie des Crustacés Décapodes Brachyoures. Mém. Mus. Natn. Hist. Nat. Paris (A) 112: 1-354.

Guinot D., Bouchard M. 1998. Evolution of the abdominal holding systems of brachyuran crabs (Crustacea, Decapoda, Brachyura). Zoosystema 20 (4): 613-694.

Hendrickx M.E. 1995. Checklist of brachyuran crabs (Crustacea: Decapoda) from the eastern tropical Pacific. Bull. K. Belg. Inst. Nat. Wet. 65: 125-150.

Holthuis L.B. 2001. Nomenclatural notes on Mediterranean species of Calappa Weber, 1795 (Crustacea: Decapoda: Brachyura). Zool. Verh. Leiden 334: 99-102. 
Hultgren K.M., Stachowicz J.J. 2008. Molecular phylogeny of the brachyuran crab superfamily Majoidea indicates close congruence with trees based on larval morphology. Mol. Phylogenet. Evol. 48(3): 986-996.

http://dx.doi.org/10.1016/j.ympev.2008.05.004

Katsanevakis S., Poursanidis D., Yokes B., et al. 2011. Twelve years after the introduction of the crab Percnon gibbesi $(\mathrm{H}$. Milne Edwards, 1853) in the Mediterranean: current distribution and invasion rates. J. Biol. Res. (Thessaloniki) 16: 224-236.

Kitsos M.S., Doulgeraki S., Tselepides A., et al. 2005. Diet composition of the bathyal crabs, Chaceon mediterraneus Manning and Holthuis and Geryon longipes A. Milne-Edwards (Decapoda, Geryonidae) collected at different depths in the eastern Mediterranean. Crustaceana 78(2): 171-184. http://dx.doi.org/10.1163/1568540054020569

Manning R.B., Chace F.A. 1990. Decapod and stomatopod crustacea from Ascension Island, South Atlantic Ocean. Smiths. Contr. Zool. 503: i-v + 1-91.

Manning R.B., Holthuis L.B. 1989. Two new genera and nine new species of geryonid crabs (Crustacea, Decapoda, Geryonidae). Proc. Biol. Soc. Wash. 102(1): 50-77.

Marco-Herrero E., Torres A.P., Cuesta J.A., et al. 2013a. The systematic position of Ergasticus (Decapoda, Brachyura) and allied genera, a molecular and morphological approach. Zool. Scripta 42(4): 427-439. http://dx.doi.org/10.1111/zsc.12012

Marco-Herrero E., Guerao G., Cuesta, J.A. 2013b. Morphology of the larval stages from a Mediterranean population of the allochthonous Say's mud crab, Dyspanopeus sayi (Decapoda: Brachyura: Panopeidae). Sci. Mar. 77(2): 341-352. http://dx.doi.org/10.3989/scimar.03815.15A

Martin J.W., Davis G.E. 2001. An updated classification of the recent Crustacea. Sci. Ser. Nat. Hist. Mus. Angeles 39: i-vii, 1-124.

Martínez J., Adarraga I. 2006. Programa de vigilancia y control de introducción de especies invasoras en los ecosistemas litorales de la costa vasca. 1. Costa de Gipuzkoa. Informe de la Sociedad Cultural de Investigación Submarina, 267 pp.

Mavidis M., Kitsos M., Turkay M., et al. 2009. The taxonomical status of the genus Pilumnus Leach, 1815 (Pilumnidae, Decapoda, Crustacea) in the Mediterranean Sea, focusing on three species in the Aegean Sea. J. Biol. Res. 11: 13-20.

Mavidis M., Turkay M., Koukouras A. 2008. The genera Atergatis, Microcassiope, Monodaeus, Paractea, Paragalene, and Xantho (Decapoda, Xanthidae) in the Mediterranean Sea. Crustaceana 81: 1035-1053. http://dx.doi.org/10.1163/156854008X360798

Milne-Edwards A., Bouvier E.-L. 1898. Crustacés nouveaux provenant des campagnes du Travailleur et du Talisman. Bull. Mus. d'Hist. Nat. 4(2): 75-77.

Milne-Edwards A., Bouvier E.-L. 1900. Crustacés décapodes. Première partie. Brachyures et anomoures, in Expéditions scientifiques du Travailleur et du Talisman pendant les années 1880, 1881, 1882, 1883. Masson, Paris, 396 p.

Müller C. 2001. Erstnachweis der flachkrabbe Percnon gibbesi (Crustacea: Decapoda: Grapsidae) für die balearischen inseln. Senck. Marit. 31(1): 83-89.

Neumann V. 1998. A review of the Maja squinado (Crustacea: Decapoda: Brachyura) species-complex with a key to the eastern Atlantic and Mediterranean species of the genus. J. Nat. Hist. 32(10-11): 1667-1684. http://dx.doi.org/10.1080/00222939800771191

Neves A.M. 1978. Macropipus zariquieyi Gordon, 1968 (Decapoda, Brachyura) species nueva para a fauna portuguesa. Bol. Soc. Port. Cienc. Nat. 18: 19-21.

Ng P.K., Guinot D., Davie P.J. 2008. Systema brachyurorum: Parte I. An annotated checklist of extant brachyuran crabs of the world. Raff. Bull. Zool. 17: 1-286.

Noël P.Y., Guinot D. 1983. Non-indigenous freshwater crabs in France: a new occurrence of a potamid near Nice. In: Gherardi F. (ed.), Biological Invaders in Inland Waters: Profiles, Distribution and Threats. Springer, pp. 77-90.

Noël P.Y., Tardy E., d'Udekem d'Acoz C. 1997. Will the crab Hemigrapsus penicillatus invade the coasts of Europe? C. R. Acad. Sci. Paris, III: Sciences de la Vie 320: 741-745.

Nunes-Ruivo L. 1961. Crustacea Decapoda (I Galatheidea et Brachyura). In Résultats scientifiques de la campagne du N.R.P. « Faial» dans les eaux côtières du Portugal (1957) 4: 1-36 + pl. $1-2$

Oliveira-Biener U., Melzer R.R., Miller M.A. 2010. Pilumnus Leach (Decapoda: Pilumnidae Samouelle) from Mediterranean and adjacent Atlantic waters: a COI analysis. Invertebr. Syst. 24: $182-193$

http://dx.doi.org/10.1071/IS09051

Osório B. 1905. Breve contribuição para o conhecimento da fauna cârcinologica de Portugal. Journ. Sci. math. phys. Nat. Lisboa, ser. 2, 7: 149-150.

Pastore M. 1995. The genus Calappa in the Ionian Sea. Oebalia 21: 187-196.

Ramalhosa P., Canning-Clode J., Biscoito M. 2014. First record of Pisa carinimana (Decapoda: Epialtidae) from Madeira Island (Northeastern Atlantic Ocean). Bocagiana 239: 1-7.

Reuschel S., Schubart C.D. 2006. Phylogeny and geographic differentiation of Atlanto-Mediterranean species of the genus Xantho (Crustacea: Brachyura: Xanthidae) based on genetic and morphometric analyses. Mar. Biol. 148(4): 853-866. http://dx.doi.org/10.1007/s00227-005-0095-1

Ribeiro F., Veríssimo A. 2014. A new record of Callinectes sapidus in a western European estuary (Portuguese coast). Mar. Biodiver. Rec. 7: e36. http://dx.doi.org/10.1017/S1755267214000384

Schubart C.D., Aichinger B.E. 2013. Determination of evolutionary units in European representatives of the crab genus Pilumnus. Cent. Eur. J. Biol. 9(1): 104-113 http://dx.doi.org/10.2478/s11535-013-0242-5

Schubart C.D., Cuesta J.A. 2010. Phylogenetic relationships of the Plagusiidae Dana, 1851, (Brachyura) with description of a new genus and recognition of Percnidae Števčić, 2005, as an independent family. Crustaceana Monographs (Studies on Brachyura: a Homage to Danièle Guinot) 11: 279-299.

Schubart C.D., Reuschel S. 2009. A proposal for a new classification of Portunoidea and Cancroidea (Brachyura: Heterotremata) based on two independent molecular phylogenies. In: Martin J.W, Crandall K.A, Felder D.L. (eds), Decapod Crustacean Phylogenetics. Crustacean Issues 18: 533-549. http://dx.doi.org/10.1201/9781420092592-c27

Schubart C.D., Cuesta J.A., Rodriguez A. 2001. Molecular phylogeny of the crab genus Brachynotus (Brachyura: Varunidae) based on the 16S rRNA gene. Hydrobiologia, 449: 41-46. http://dx.doi.org/10.1023/A:1017564229866

Schubart C.D., Cuesta J.A., Felder D.L. 2002. Glyptograpsidae, a new brachyuran family from Central America: larval and adult morphology, and a molecular phylogeny of the Grapsoidea. J. Crustac. Biol. 22(1): 28-44. http://dx.doi.org/10.1163/20021975-99990206

Schubart C.D., Guerao G., Abelló P. 2012. First record and evidence of an established population of the North American mud crab Dyspanopeus sayi (Brachyura: Heterotremata: Panopeidae) in the western Mediterranean. Sci. Mar. 76(1): 79-85. http://dx.doi.org/10.3989/scimar.03361.16A

Sotelo G., Morán P., Fernández L., et al. 2008. Genetic variation of the spiny spider crab Maja brachydactyla in the northeastern Atlantic. Mar. Ecol. Prog. Ser. 362: 211-223. http://dx.doi.org/10.3354/meps07433

Spiridonov V.A., Neretina T.V., Schepetov D. 2014. Morphological characterization and molecular phylogeny of Portunoidea Rafinesque, 1815 (Crustacea Brachyura): Implications for understanding evolution of swimming capacity and revision of the family-level classification. Zool. Anz. 253(5): 404-429.

Spivak E.D., Cuesta J.A. 2009. The effect of salinity on larval development of Uca tangeri (Eydoux, 1835) (Brachyura: Ocypodidae) and new findings of the zoeal morphology. Sci. Mar. 73(2): 297-305. http://dx.doi.org/10.3989/scimar.2009.73n2297

Subida M.D., Arias A.M., Drake P., et al. 2011. On the occurrence of Afropinnotheres monodi Manning, 1993 (Decapoda: Pinnotheridae) in European waters. J. Crustac. Biol. 31(2): 367-369. http//dx.doi.org/10.1651/10-3381.1

Tan S.H., Ng P. K. 2007. Descriptions of new genera from the subfamily Parthenopinae (Crustacea: Decapoda: Brachyura: Parthenopidae). Raff. Bull. Zool. 16: 95-119.

Türkay M. 1975. Zur Kenntnis der Gattung Euchirograpsus mit Bemerkungen zu Brachygrapsus und Litocheira (Crustacea, Decapoda). Senck. Biol. 56(1/3): 103-132.

Türkay M. 1976. Decapoda Reptantia von der portugiesischen und marokkanischen Küste. Auswertung der Fahrten 8, 9c (1967), 23 (1971) und 36 (1975) von F.S. "Meteor". "Meteor" Forschungserg. (D) 23: 23-44.

Türkay M. 1987. On the Mediterranean and eastern Atlantic records of Portunus sayi Crustacea Decapoda Portunidae. Inv. Pesq. 51 Suppl. 1: 63-66. 
Türkay M. 2001. Decapoda. In: Costello M.J., Emblow C., White R.: European register of marine species. A check-list of the marine species in Europe and a bibliography of guides to their identification. Patrimoines Naturels 50: 284-292.

Urgorri V., Solorzano M.R., Besteiro C., et al. 1990. Crustáceos Decápodos Braquiuros de Galicia existentes en las colecciones del Museo de Historia Natural «Luis Iglesia» (Galicia). Bol. R. Soc. Esp. Hist. Nat. (Sec. Biol.) 85(1-4): 5-15

Verges A., Steinberg P.D., Hay M.E., et al. 2014 The tropicalization of temperate marine ecosystems: climate-mediated changes in herbivory and community phase shifts. Proc. R. Soc. London (Biol.) 281(1789): 20140846. http://dx.doi.org/10.1098/rspb.2014.0846

Vilela H. 1936. Coleção oceanografica de D. Carlos I. Catálogo dos Crustáceos Decapodes e Estomatópodes. Bull. Soc. Portug. Sci. Nat. 12: 215-242.

Zariquiey Álvarez R. 1968. Crustáceos decápodos ibéricos. Inv. Pesq., Barcelona 32: i-xv + 1-510.

Zenetos A., Gofas S., Verlaque V., et al. 2010. Alien species in the Mediterranean Sea by 2010. A contribution to the application of European Union's Marine Strategy Framework Directive (MSFD). Part I. Spatial distribution. Medit. Mar. Sci. 11/2: 381-493.

http://dx.doi.org/10.12681/mms.87 